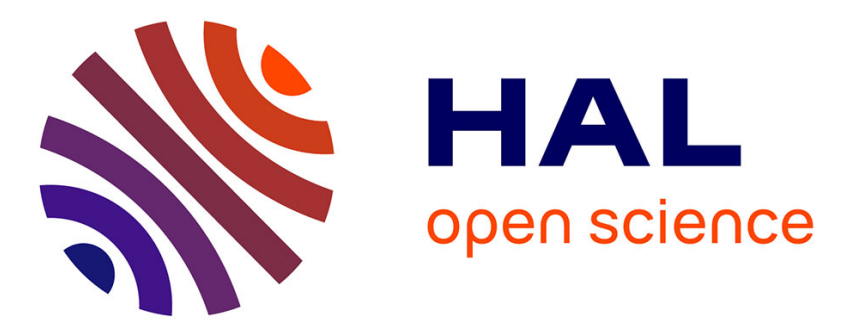

\title{
Influence of Ergometer Design on Physiological Responses during Rowing
}

Jérémy Rossi, Enzo Piponnier, Loic Vincent, Pierre Samozino, Laurent Messonnier

\section{- To cite this version:}

Jérémy Rossi, Enzo Piponnier, Loic Vincent, Pierre Samozino, Laurent Messonnier. Influence of Ergometer Design on Physiological Responses during Rowing. International Journal of Sports Medicine, 2015, 36 (11), pp.947-951. 10.1055/s-0035-1548810 . hal-02078525

\section{HAL Id: hal-02078525 \\ https://hal.science/hal-02078525}

Submitted on 29 Oct 2019

HAL is a multi-disciplinary open access archive for the deposit and dissemination of scientific research documents, whether they are published or not. The documents may come from teaching and research institutions in France or abroad, or from public or private research centers.
L'archive ouverte pluridisciplinaire HAL, est destinée au dépôt et à la diffusion de documents scientifiques de niveau recherche, publiés ou non, émanant des établissements d'enseignement et de recherche français ou étrangers, des laboratoires publics ou privés. 
International Journal

of Sports Medicine

\section{Influence of ergometer design on physiological responses during rowing}

\section{J. Rossi, E. Piponnier, L. Vincent, P. Samozino, L. Messonnier}

\begin{tabular}{|c|c|}
\hline Journal: & International Journal of Sports Medicine \\
\hline Manuscript ID: & IJSM-09-2014-4455-tt.R2 \\
\hline Manuscript Type: & Training \& Testing \\
\hline Key word: & oxygen uptake, lactate, rowing efficiency, submaximal exercise \\
\hline Abstract: & $\begin{array}{l}\text { The aim of this study was to compare the physiological responses and } \\
\text { rowing efficiency on two different rowing ergometers: the Concept } 2 \\
\text { stationary versus dynamic ergometers. Eleven oarswomen and oarsmen } \\
\text { rowed four minutes at } 60 \% \text { and } 70 \% \text { of peak power output on both } \\
\text { ergometers (randomized order). Power output, stroke rate, heart rate, } \\
\text { oxygen uptake, carbon dioxyde production, lactate accumulation and rating } \\
\text { of perceived exertion were recorded at each stage on the two ergometers. } \\
\text { Gross and net efficiencies were computed. Exercise intensity was } \\
\text { associated with increases in all parameters. Rowing on dynamic ergometer } \\
\text { was associated with higher heart rate, oxygen uptake, carbon dioxyde } \\
\text { production and stroke rate, concomitantly to lower blood lactate } \\
\text { accumulation but also lower gross and net efficiencies. The present study } \\
\text { showed that rowing efficiency and blood lactate accumulation were lower } \\
\text { on the Concept2 dynamic ergometer than on its stationary counterpart. If } \\
\text { the use of the Concept } 2 \text { dynamic ergometer may provide some advantages } \\
\text { (reduced risk of injuries), its utilisation requires specific evaluation of } \\
\text { physiological responses during an incremental exercise for an adapted } \\
\text { management of training. }\end{array}$ \\
\hline
\end{tabular}


2

4

5
6

6
7

83

5

5

5

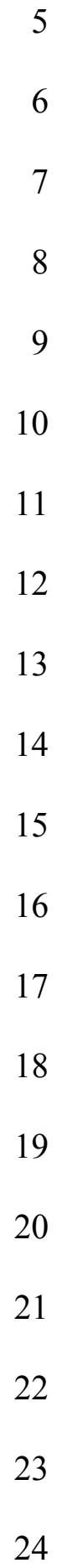




\section{ABSTRACT}

26 The aim of this study was to compare the physiological responses and rowing efficiency on two

27 different rowing ergometers: the Concept2 stationary versus dynamic ergometers. Eleven 28 oarswomen and oarsmen rowed four minutes at $60 \%$ and $70 \%$ of peak power output on both 29 ergometers (randomized order). Power output, stroke rate, heart rate, oxygen uptake, carbon 30 dioxyde production, lactate accumulation and rating of perceived exertion were recorded at each 31 stage on the two ergometers. Gross and net efficiencies were computed. Exercise intensity was 32 associated with increases in all parameters. Rowing on dynamic ergometer was associated with 33 higher heart rate, oxygen uptake, carbon dioxyde production and stroke rate, concomitantly to 34 lower blood lactate accumulation but also lower gross and net efficiencies. The present study 35 showed that rowing efficiency and blood lactate accumulation were lower on the Concept2 36 dynamic ergometer than on its stationary counterpart. If the use of the Concept2 dynamic 37 ergometer may provide some advantages (reduced risk of injuries), its utilisation requires specific 38 evaluation of physiological responses during an incremental exercise for an adapted management 39 of training.

40

41 Keywords: oxygen uptake, lactate, rowing efficiency, submaximal exercise 42 


\section{INTRODUCTION}

Rowers extensively use rowing ergometers for training, especially during the winter season.

47 Ergometers are also used to evaluate the performance level of the rowers and their physiological

48 characteristics such as maximal oxygen uptake and blood lactate kinetics in response to exercise

49 which are closely related to rowing performance on water and on ergometer [18,23]. In that

50 sense, results obtained on ergometers are sometimes used as selection criteria by some rowing

51 national teams [11]. Although to a lower extent than on water, performance on ergometer is also

52 related to mechanical efficiency [4,12]. On classic stationary ergometers, previous experiments,

53 but not all [25], have shown that rowing efficiency increased when exercise power output

54 augmented $[4,9,22]$. This increase in rowing efficiency with work rate may at least in part

55 account for the higher gross efficiency observed in adults than in young rowers since the former

56 exercised at higher power outputs [22].

57 Dynamic ergometers have been developed in order to mimic more closely on-water rowing 58 movement and feelings [7]. Contrary to the stationary design where the rower moves forth and

59 back on the ergometer, the centre of mass of the rower is much less displaced on the dynamic 60 ergometers where it is the system that moves: foot stretcher and flywheel on RowPerfect or 61 ergometer as a whole in the case of Concept 2 with slides. Furthermore, the total mass of the 62 system that moves is lower than the mass of the rower [15]. In that case, the energy spent to move 63 the body of the rower [6,9] and the system (vide supra) back and forth might be lower on the 64 dynamic ergometers since the inertial forces to develop for each stroke are expected to be lower. 65 Following this line of reasoning, rowing efficiency can be expected to be higher on the dynamic 66 ergometers. However, and although peak handle forces were also lower on the dynamic 67 ergometers $[1,5,15]$, the physiological responses to a given exercise intensity have been observed 68 to be comparable on stationary and dynamic ergometers [15,19], suggesting similar overall 
69 energy expenditure and consequently rowing efficiency on the two ergometer designs. Worst,

70 contrary to this inference, Benson et al. [1] found lower rowing efficiency at maximal pace on

71 dynamic rowing ergometer than on the stationary. They attributed these alterations in rowing 72 efficiency to the higher stroke rate on the dynamic ergometer, inducing higher energy 73 expenditure. They also evoked the low rowing performance level of their subjects. Indeed, these 74 alterations in rowing efficiency have not been observed in oarswomen of higher ranking. 75 Nevertheless, Holsgaard-Larsen and Jensen [15] also reported a lower economy while rowing on 76 slides (dynamic condition) than without (stationary) in high-level Danish rowers. They also 77 attributed this lower efficiency to the higher stroke rate on the dynamic ergometer.

78 Recently, a new dynamic ergometer appeared (Dynamic, Concept 2, Morriswille, USA). In 79 that new frame, only the segments of the rower and the stretcher move, so that the masses to 80 displace are minimised. This could induce a lower internal mechanical work to accelerate the 81 segments mass at each stroke, which could result in a higher efficiency than on other dynamic 82 design ergometers. Consequently, it is possible that the difference in rowing efficiency between 83 the brand-new dynamic and other stationary ergometers does not exist anymore, despite still a 84 higher stroke rate on the former device.

85 Thus, the aim of this study was to compare the physiological responses and rowing 86 efficiency on two different rowing ergometers: the Concept2 stationary (model D) versus 87 dynamic ergometers. Specifically, we hypothesized that the higher energy expenditure related to 88 stroke rate would be compensated by a low energy expenditure related to the masses to displace, 89 so that rowing efficiency would be similar on the dynamic and stationary Concept 2 rowing 90 ergometers. 


\section{METHODS}

\section{Study population}

94 Eleven competitive rowers, 6 men and 5 women (age: 20.0 2.6 years, body mass: $9571.4 \pm 12.5 \mathrm{~kg}$, height: $176 \pm 13 \mathrm{~cm}$ and body fat: $15.0 \pm 5.2 \%$ ) participated in this study. The 96 present study was approved by the local ethics committee $\left(\mathrm{n}^{\circ}: 20145\right)$ and was performed in 97 accordance with the ethical standards of the IJSM [14] Before giving their written consent, the 98 subjects were fully informed of the objectives, experimental design, all risks, possible 99 discomforts, and potential benefits of the experiments.

100

$101 \quad$ Ergometers

102 Two rowing ergometers with different designs were used: a stationary (fixed-foot stretcher) 103 rowing ergometer (SRE: model D, Concept2, Morrisville, VT, USA; Figure 1a) and a dynamic 104 (free-floating stretcher) rowing ergometer (DRE: dynamic, Concept2, Morrisville, VT, USA;

105 Figure 1b). The two rowing ergometers were new at the time of the experiment. They were 106 equipped with Concept2 Performance Monitor 4 (PM4) calculator (Concept2, Morrisville, VT, 107 USA), which measures stroke rate $\underline{\left(\text { cycles . } \mathrm{m}^{-1}\right)}$ and mean power outputs $\underline{(\mathrm{W})}$ continuously. Both 108 ergometers were equipped with the same PM4 calculator giving the same power output 109 measurements in both conditions. Note that these PM4 calculators are actually used for 110 international and national indoor rowing competitions and in many scientific studies [1,16,17]. 111 Subjects were thus able to adjust exercise intensity according to the required power output.

113 Experimental Design

114 The experiment consisted successively in i) a familiarisation period, ii), an incremental 115 exercise up to exhaustion, and iii) a standardized submaximal exercise session. 
116 Familiarization period. All subjects underwent eight of their regular training sessions on

117 rowing ergometer in the laboratory. Each training session lasted between 40 and 60 min each.

118 Half of the training session was performed on one of the ergometer and the other half on the other

119 ergometer. The order between SRE and DRE was randomized. This procedure allowed the

120 rowers to become accustomed with the environment and the dynamic ergometer.

121 Incremental exercise up to exhaustion (session1). The graded exercise was performed on

122 SRE. It started at $120 \mathrm{~W}$ for the women and $150 \mathrm{~W}$ for the men. After 3 min of exercise at this

123 load, the work rate was increased by $35 \mathrm{~W}$ for the women and $50 \mathrm{~W}$ for the men every 3 min

124 thereafter. The exercise was stopped when the subjects were no longer able to sustain the work

125 rate. This exercise session was performed for determination of maximal heart rate $\left(\mathrm{HR}_{\text {peak }}\right.$,

126 beats/min) and peak power output $\left(\mathrm{P}_{\text {peak }}, \mathrm{W}\right)[3]$.

$127 \quad$ Standardized submaximal exercises (session 2). This session intervened at least 3 days after

128 the incremental exercise. After 10 min of self conducted light warm-up, rowers performed on

129 SRE and DRE ergometers three consecutive exercises of 4-min duration each at 50\% (to

130 standardize the end of the warm-up and reach a steady state level for all rowers), $60 \%$ and $70 \%$ of

$131 \mathrm{P}_{\text {peak }}$, respectively. After a 20-min rest period, rowers performed the same exercise procedure but

132 on the other ergometer. The order of ergometers was randomized between subjects. The

133 participants were asked to adopt their preferred stroke rate during rowing on each ergometer.

134 Drag factor was set on both ergometers at 110 and 130 for women and men, respectively. These

135 values of drag factor were i) those used by the rowers of the present study during their training

136 sessions and during indoor rowing competitions, and ii) in accordance with those

137 advocated/recommended [13].

138

139

Measurements 
140 Oxygen uptake $\left(\mathrm{VO}_{2}\right)$, carbon dioxyde production $\left(\mathrm{VCO}_{2}\right)$ and respiratory exchange ratio

$141 \quad\left(\mathrm{VCO}_{2} / \mathrm{VO}_{2}\right)$ were measured by portable system for pulmonary gas exchange measurements using 142 a breath-by-breath analysis device ( $\mathrm{K} 4 \mathrm{~b}^{2}$, Cosmed, Rome, Italy) and averaged over $15 \mathrm{~s}$. These 143 variables were recorded every 15 s during the last minute of each stage of sessions 1 and 2 and 144 averaged. Heart rate (HR) was recorded continuously (RS800CX, Polar, Finland) during session 1451 and 2 while rating of perceived exertion (RPE) was recorded using the 15-point Borg scale (6146 20) after each of the two studied intensities (i.e., 60 and $70 \%$ of $\mathrm{P}_{\text {peak}}$ ). Lactate concentration was 147 measured on capillary blood samples taken from micropunctures performed at the earlobe at the 148 end of all exercise intensity stages (i.e., 60 and $70 \% \mathrm{P}_{\text {peak}}$ ) using a Lactate Scout (EKF 149 diagnostics, Barleben, Germany). In that purpose, submaximal exercises were separated by thirty 150 seconds of rest. Lactate accumulation $\left(\Delta[\mathrm{La}]\right.$, mmol. $\left.1^{-1}\right)$ during stages of the two studied 151 intensities (i.e., 60 and $70 \%$ of $\mathrm{P}_{\text {peak }}$ ) were calculated.

\section{Calculations}

154 Standard equations were used to estimate the percentages of energy derived from $\mathrm{CHO}$ 155 (\%CHOox) and lipid (\%Lipidox) as well as their absolute oxidation rates (CHOox and Lipidox, 156 respectively). These calculations take into account a non-protein $\mathrm{VO}_{2}$ and $\mathrm{VCO}_{2}$ (considering a 157 standard protein oxidation rate leading to urinary nitrogen excretion of $0.01 \mathrm{~g} \cdot \mathrm{min}^{-1}$ ) and 158 providing a non-protein respiratory quotient (NPRQ) [8,29].

$$
\mathrm{CHO}=4.55 \cdot \mathrm{VCO}_{2}-3.21 \cdot \mathrm{VO}_{2}-2.87 \cdot 0.01 \quad\left(\mathrm{~g} \cdot \mathrm{min}^{-1}\right)
$$

$$
\text { Lipid }=1.67 \cdot \mathrm{VO}_{2}-1.67 \cdot \mathrm{VCO}_{2}-1.92 \cdot 0.01
$$$$
\left(\mathrm{g} \cdot \mathrm{min}^{-1}\right)
$$

161

$$
\mathrm{NPRQ}=\left[\mathrm{VCO}_{2}-(0.01 \cdot 4.89)\right] /\left[\mathrm{VO}_{2}-(0.01 \cdot 6.04)\right]
$$

Therefore, 
163

164

165

166

172

$$
\% \text { CHOox }=[(\mathrm{NPRQ}-0.707) / 0.293] \cdot 100
$$$$
\mathrm{CHOox}=(\% \mathrm{CHOox} / 100) \cdot \mathrm{VO}_{2} \cdot 5.05
$$$$
\text { \%Lipidox }=(100-\% \text { CHOox })
$$$$
\text { Lipidox }=(\% \text { Lipidox } / 100) \cdot \mathrm{VO}_{2} \cdot 4.7
$$

$(\%)$

$$
\left(\mathrm{kcal} \cdot \mathrm{min}^{-1}\right)
$$

$\left(\mathrm{kcal} \cdot \mathrm{min}^{-1}\right)$
(Eq. 5)

167 where: 5.05 and 4.7 are the numbers for kilocalories provided from $\mathrm{CHO}$ and lipid per liter of

168 consumed oxygen, respectively.

169 Because lactate accumulation $(\Delta[\mathrm{La}])$ was really modest, the "lactic" component in energy

170 supply was neglected [20]. Therefore, metabolic power $\left(\mathrm{P}_{\text {metab }}\right)$ during exercise was computed as

171 the sum of CHOox and Lipidox, divided by 69.78 to obtain results in watts.

173 Efficiencies

174 Gross and net efficiencies were calculated as proposed by Gaesser and Brooks [10]:

$175 \quad \mathrm{GE}=\mathrm{P}_{\text {mecha }} / \mathrm{P}_{\text {metab }}$

$176 \quad \mathrm{NE}=\mathrm{P}_{\text {mecha }} /\left(\mathrm{P}_{\text {metab }}-\mathrm{P}_{\text {rest }}\right)$

177 where GE is gross efficiency, NE is net efficiency, $\mathrm{P}_{\text {mecha }}$ is actual mechanical power output, and

$178 \mathrm{P}_{\text {rest }}$ is resting metabolic power taking into account a resting $\mathrm{VO}_{2}$ of $5.0 \mathrm{ml} \cdot \mathrm{min}^{-1} \cdot \mathrm{kg}^{-1}$ [20].

180 Statistical analysis

181 Mean values and standard deviations were calculated for each variable. Normal distribution

182 of the data was checked by the Shapiro-Wilk normality test. A two-way $($ Ergometer $\times$ Intensity)

183 analysis of variance (ANOVA) with repeated measures was used to determine the effects of 184 ergometer and intensity on each variable. Significant results were followed by post-hoc 
1

2

3

4

5

6

7

8

9

10

11

12

13

14

15

16

17

18

19

20

21

22

23

24

25

26

27

28

29

30

31

32

33

34

35

36

37

38

39

40

41

42

43

44

45

46

47

48

49

50

51

52

53

54

55

56

57

58

59

60
185 comparisons using Newman-Keuls post-hoc tests. The critical level of significance was set to $186 \mathrm{p} \leq 0.05$.

187

Georg Thieme Verlag KG. P. O. Box 3011 20, D-70451 Stuttgart, Germany. http://www.thieme.de/fz/sportsmed/index.html 
RESULTS

189

A comparison of mean mechanical, physiological, psychological and kinematic variables recorded during submaximal exercise on SRE and DRE is summarized in table 1.

191

192

\section{Effect of exercise Intensity}

The repeated-measures ANOVA showed a significant effect of exercise Intensity on power

194 output $\left(\mathrm{F}_{(1,10)}=110.808\right)$, heart rate $\left(\mathrm{F}_{(1,10)}=91.605\right)$, $\mathrm{RPE} \quad\left(\mathrm{F}_{(1,10)}=54.950\right)$, blood lactate 195 accumulation $\left(\mathrm{F}_{(1,10)}=5.502\right), \quad \mathrm{VO}_{2} \quad\left(\mathrm{~F}_{(1,10)}=136.859\right), \quad \mathrm{VCO}_{2} \quad\left(\mathrm{~F}_{(1,10)}=204.933\right), \quad$ stroke rate $196\left(\mathrm{~F}_{(1,10)}=17.396\right)$ (table 1$)$. Gross efficiency $\left(\mathrm{F}_{(1,10)}=17.046\right)$ was on average 5.3\% higher at $70 \%$ 197 compared to $60 \%$ of $\mathrm{P}_{\text {peak }}$ and net efficiency $\left(\mathrm{F}_{(1,10)}=8.173\right)$ was $3.4 \%$ lower at $60 \%$ than $70 \%$ of $198 \mathrm{P}_{\text {peak }}($ table 1$)$

\section{Effect of Ergometer}

201 No difference was observed on power output and RPE between SRE and DRE. On the 202 contrary, significantly higher heart rates $\left(\mathrm{F}_{(1,10)}=12.930\right)(2.5 \%$ and $2.5 \%$ for $60 \%$ and $70 \%$ 203 exercise intensity, respectively) and stroke rates $\left(\mathrm{F}_{(1,10)}=9.861\right)$ were observed on DRE compared 204 to SRE. Moreover, $\mathrm{VO}_{2}\left(\mathrm{~F}_{(1,10)}=13.731\right)$ and $\mathrm{VCO}_{2}\left(\mathrm{~F}_{(1,10)}=8.630\right)$ were significantly higher (by $2055.1 \%$ and $4.6 \%$, respectively) on the DRE compared to SRE. Consequently, statistical analysis 206 showed a significant effect of Ergometer on gross efficiency $\left(\mathrm{F}_{(1,10)}=12.694\right)$ which was on 207 average 5.1\% higher on the SRE compared to DRE (Figure $2 \mathrm{a})$ and net efficiency $\left(\mathrm{F}_{(1,10)}=13.133\right)$ 208 which was on average 5.4\% higher on the SRE compared to DRE (Figure 2b). However, it is 209 interesting to note that blood lactate accumulation was significantly lower on DRE than on SRE $210 \quad\left(\mathrm{~F}_{(1,10)}=5.734\right)$. 


\section{DISCUSSION}

213 The aim of the present study was primarily to compare rowing efficiency on Concept2

214 stationary and dynamic ergometers. Specifically, we hypothesized that rowing efficiency would

215 not be different between the two ergometers. Contrary to this hypothesis, rowing efficiency was

216 significantly lower on the dynamic Concept2 rowing ergometer than on the stationary. Another

217 unexpected result of the present study was that blood lactate accumulation was lower on the

218 dynamic ergometer than on the stationary.

220 Effect of exercise intensity

221 As expected, $\mathrm{HR}, \mathrm{RPE}, \mathrm{VO}_{2}, \mathrm{VCO}_{2}$, lactate accumulation and stroke rate were higher at $22270 \%$ than at $60 \% \mathrm{P}_{\text {peak. }}$. Gross and net efficiencies were also higher at $70 \%$ than at $60 \% \mathrm{P}_{\text {peak }}$. This 223 result is not surprising on the stationary ergometer. Previous experiments, but not all [25], have 224 shown that rowing efficiency increased when exercise power output augmented $[9,12,22]$. The 225 new information concern the dynamic ergometer for which the same evolution pattern is 226 observed i.e., rowing efficiency is higher at $70 \%$ than at $60 \% \mathrm{P}_{\text {peak. }}$. Interestingly, the increase in 227 efficiency from $60 \%$ to $70 \% \mathrm{P}_{\text {peak }}$ is of similar magnitude on the stationary and dynamic 228 ergometers (concerning gross efficiency $+5.2 \%$ and $+4.8 \%$ for SRE and DRE, respectively; 229 concerning net efficiency $+4.1 \%$ and $+3.8 \%$ for SRE and DRE, respectively).

231 Effect of ergometer

232 Contrary to our hypothesis, gross and net rowing efficiencies were still lower on the 233 dynamic than on the stationary ergometer. In the present study, gross efficiency was $4.7 \%$ and $2345.2 \%$ higher on DRE than on SRE at $60 \%$ and $70 \% \mathrm{P}_{\text {peak }}$, respectively. Moreover, the difference 235 between DRE and SRE was not even reduced by the new frame from Concept2. Indeed, Benson 
236 et al. [1] found a 5.6\% difference in economy at maximal power on Concept 2 with and without

237 slides and Holsgaard-Larsen and Jensen [15] found 4.3\% and 2.6\% differences in gross efficiency 238 at $40 \%$ and $55 \%$ on fixed and free RowPerfect dynamic ergometer. Thus, the reduction of the

239 displacement of the body centre of mass on the dynamic Concept 2 ergometer which should had 240 reduced the internal mechanical work to accelerate the segments mass at each stroke is not 241 sufficient to counterbalance the other factors contributing to increase the energy expenditure.

242 Note that the kinetic mechanical energy require to move the body mass relative to the ergometer 243 is a priori associated with "internal" work since it does not contribute directly to the power 244 output on rowing ergometers. As a whole, the kinetic internal work seems to have low impact on 245 the mechanical efficiency, which is in line with the similar gross efficiency reported in 246 lightweight and heavyweight rowers by Bourdin et al. [3].

247 As it has been previously reported for other dynamic ergometers $[1,5,15]$, stroke rate was

248 higher on the dynamic Concept 2 than on the stationary ergometer. As Benson et al. [1] and 249 Holsgaard-Larsen and Jensen [15] did, we could incriminate the higher stroke rate (which 250 induces an extra energy expenditure for body mass displacement) to explain the lower efficiency 251 on DRE than on SRE. However, the literature is consistent with the fact that the higher stroke rate 252 on DRE is counterbalanced by lower peak force development on this type of ergometer $[1,5,15]$, 253 that should induce a lower energy expenditure and mitigate the negative effect of the higher 254 stroke rate, but again this does not seem to be the case. Because i) work rate was the same and ii) 255 stroke rate was higher on the dynamic ergometer, we can speculate that the cycle-averaged 256 handle force was lower on the DRE. Our results, interpretation and speculation are reminiscent 257 with the results of Colloud et al. [5] who found, for similar drag factors and stroke rate, lower 258 handle force and power output on the dynamic ergometer than on the stationary one. 
259 One possible explanation for the consistent higher ergometer rowing efficiency on SRE 260 may be that the kinetic work required to accelerate the body centre of mass at each stroke is 261 partly transferred/transformed as external (propulsive) work in the second part of the drive phase.

262 Consequently, the higher energy expenditure associated with this internal work is partly used to 263 produce power output, and in turn contribute to increase mechanical efficiency. This advantage, 264 in addition to a lower stroke rate, may at the end lead to a higher rowing efficiency on the SRE 265 than on the DRE.

266 An unexpected result of the present study was that blood lactate accumulation was lower on 267 the DRE than on the SRE. This result was consistent whatever the work rate i.e., $60 \%$ or $70 \%$ $268 \mathrm{P}_{\text {peak }}($ Table 1). At the present time, one can only speculate on the fact that the lower peak force 269 for a given power output during rowing on DRE than on SRE may preferentially involve 270 oxidative fibres and metabolism that may induce a lower lactate production and a higher $271 \mathrm{removal} /$ recycling $[2,24,26,27,28]$. However, this hypothesis should be taken with caution since 272 to our knowledge, no studies have investigated to date the effects of changing the couple 273 force/motion frequency on lactate kinetic parameters i.e., production, exchange and removal.

\section{Effect of drag factor}

In the present study, the drag factor was set at 110 and 130 for women and men,

277 respectively. This raises the question of knowing whether the present results and interpretations

278 would have been different if other drag factors had been used. Kane et al. [16] found very little

279 effects of the drag factor on physiological aspects of rowing. Only maximal minute ventilation

280 was affected. More importantly, no physiological responses to rowing were affected by using

281 different drag factors (i.e., 100 and 150) during submaximal exercises [16], including the 
282 intensities used in the present study. So even if the drag factors had been different, it would have

283 been unlikely that the results and conclusions of the present study would have been different.

284

285

Consequences for training management and performance achievement

Rowing ergometers are extensively used during training. Results obtained during an

287 incremental exercise (mainly $\mathrm{VO}_{2}, \mathrm{HR}$ and lactate curves) are sometimes used to monitor training

288 of the athletes (e.g., [21]). If the use of a dynamic rowing ergometer can be advocated because it

289 may reflect more closely on-water rowing $[7,18]$ and reduce the risk of injuries [5] compared to a

290 stationary one, the present study highlighted that for a given power output, $\mathrm{VO}_{2}, \mathrm{HR}$ and lactate

291 accumulation are different while exercising on Concept2 SRE and DRE. Thus, the

292 transfer/application of the results obtained on a Concept2 stationary ergometer to a dynamic one

293 is not recommended. Specific evaluations of physiological responses to an incremental exercise

294 should be performed on a Concept2 DRE to manage training on this ergometer. Furthermore, the

295 lower rowing efficiency on DRE may potentially alter the ability to sustain an elevated work rate

296 over the race distance, affecting performance on this type of ergometer. However, this hypothesis

297 has never been tested and further studies are necessary to conclude on this point.

298

299 CONCLUSIONS

300 The present study showed that rowing efficiency and blood lactate accumulation were

301 lower on the Concept2 dynamic ergometer than on its stationary counterpart. If the use of the

302 Concept2 dynamic ergometer may provide some advantages (reduced risk of injuries), its

303 utilisation requires specific evaluation of physiological responses during an incremental exercise

304 for a good management of training. 
306 REFERENCES

3071 Benson A, Abendroth J, King D, Swensen T. Comparison of rowing on a concept 2 $308 \quad$ stationary and dynamic ergometer. Sports Sci Med. 2011; 10: 267-273

3092 Bergman BC, Wolfel EE, Butterfield GE, Lopaschuk GD, Casazza GA, Horning MA, 310 Brooks GA. Active muscle and whole body lactate kinetics after endurance training in 311 men. J Appl Physiol. 1999; 87: 1684-1696

3123 Bourdin M, Messonnier L, Hager JP, Lacour JR. Peak power output predicts rowing 313 ergometer performance in elite male rowers. Int J Sports Med. 2004; 25: 368-373

3144 Bourdin M, Messonnier L, Lacour JR. Laboratory blood lactate profile is suited to on 315 water training monitoring in highly trained rowers. J Sports Med Phys Fitness. 2004; 44: $316 \quad 337-341$

3175 Colloud F, Bahuaud P, Doriot N, Champely S, Chèze L. Fixed versus free-floating 318 stretcher mechanism in rowing ergometers: mechanical aspects. J Sports Sci. 2006; 24: $319 \quad 479-493$

3206 Di Prampero PE, Cortili G, Celentano F, Cerretelli P. Physiological aspects of rowing. J $321 \quad$ Appl Physiol. 1971; 31: 853-857

3227 Elliott B, Lyttle A, Birkett $O$. The RowPerfect ergometer: a training aid for on-water single 323 scull rowing. Sports Biomech. 2002; 1: 123-134

3248 Frayn KN. Calculation of substrate oxidation rates in vivo from gaseous exchange. J Appl $325 \quad$ Physiol Respir Environ Exerc Physiol. 1983; 55: 628-634

3269 Fukunaga T, Matsuo A, Yamamoto K, Asami T. Mechanical efficiency in rowing. Eur J 327 Appl Physiol Occup Physiol. 1986; 55: 471-475

32810 Gaesser GA, Brooks GA. Muscular efficiency during steady-rate exercise: effects of speed 329 and work rate. J Appl Physiol. 1975; 38: 1132-1139 
33011 Hagerman FC, Walsh SJ, Staron RS, Hikida RS, Gilders RM, Murray TF, Toma K, Ragg

$331 K E$. Effects of high-intensity resistance training on untrained older men. I. Strength, 332 cardiovascular, and metabolic responses. J Gerontol A Biol Sci Med Sci. 2000; 55: B336$333 \quad 346$

33412 Hagerman FC. Applied physiology of rowing. Sports Med. 1984; 1: 303-326

33513 Hahn A, Bourdon P, Tanner R. Protocols for the physiological assessment of rowers. In:

$336 \quad$ Gore C (ed.). Physiological Tests for Elite Athletes. Champaign, IL: Human Kinetics, $337 \quad \underline{2000 ; 317-318}$

3381314 Harriss DJ, Atkinson G. Ethical Standards in Sport and Exercise Science Research: 2014 $339 \quad$ Update. Int J Sports Med. 2013 34. 1025-1028

$340 \quad \underline{15}$ Holsgaard-Larsen A, Jensen K. Ergometer rowing with and without slides. Int J Sports $341 \quad$ Med. 2010;31: 870-874

$342 \quad 16 \quad$ Kane DA, Jensen RL, Williams SE, Watts $P B$. Effects of drag factor on physiological $343 \quad$ aspects of rowing. Int J Sports Med. 2008; 29: 390-394

3441417 Kane DA, Mackenzie SJ, Jensen RL, Watts PB. Effects of stroke resistance on rowing $345 \quad$ economy in club rowers post-season. Int J Sports Med. 2013; 34: 131-137

3461518 Mäestu J, Jürimäe J, Jürimäe T. Monitoring of performance and training in rowing. $347 \quad$ Sports Med. 2005; 35: 597-617

3481619 Mahony N, Donne B, O'Brien M. A comparison of physiological responses to rowing on 349 friction-loaded and air-braked ergometers. J Sports Sci. 1999; 17: 143-149

$350 \quad 1720$ Medbø JI, Mohn AC, Tabata I, Bahr R, Vaage O, Sejersted OM. Anaerobic capacity 351 determined by maximal accumulated O2 deficit. J Appl Physiol. 1988; 64: 50-60

3521821 Messonnier L, Aranda-Berthouze SE, Bourdin M, Bredel Y, Lacour JR. Rowing 353 performance and estimated training load. Int J Sports Med. 2005; 26: 376-382 
354 1922 Messonnier L, Bourdin M, Lacour JR. Influence de l'âge sur différents facteurs 355 déterminants de la performance sur ergomètre aviron. Science \& Sports. 1998; 13: 293$356 \quad 294$

3572023 Messonnier L, Freund H, Bourdin M, Belli A, Lacour JR. Lactate exchange and removal 358 abilities in rowing performance. Med Sci Sports Exerc. 1997; 29: 396-401

3592124 Messonnier LA, Emhoff CA, Fattor JA, Horning MA, Carlson TJ, Brooks GA. Lactate 360 kinetics at the lactate threshold in trained and untrained men. J Appl Physiol. 2013; 114: $361 \quad 1593-1602$

362 2225 Steinacker JM, Marx TR, Marx U, Lormes W. Oxygen consumption and metabolic strain 363 in rowing ergometer exercise. Eur J Appl Physiol Occup Physiol. 1986; 55: 240-247

364 2326 Tesch P, Sjödin B, Karlsson J. Relationship between lactate accumulation, LDH activity, 365 LDH isozyme and fibre type distribution in human skeletal muscle. Acta Physiol Scand. $366 \quad 1978 ; 103: 40-46$

3672427 Tesch P, Sjödin B, Thorstensson A, Karlsson J. Muscle fatigue and its relation to lactate 368 accumulation and LDH activity in man. Acta Physiol Scand. 1978; 103: 413-420

3692528 Thomas $C$, Sirvent P, Perrey S, Raynaud E, Mercier J. Relationships between maximal 370 muscle oxidative capacity and blood lactate removal after supramaximal exercise and 371 fatigue indexes in humans. J Appl Physiol. 2004; 97: 2132-2138

3722629 Zarins ZA, Wallis GA, Faghihnia N, Johnson ML, Fattor JA, Horning MA, Brooks GA. 373 Effects of endurance training on cardiorespiratory fitness and substrate partitioning in 374 postmenopausal women. Metabolism. 2009; 58: 1338-1346

375 


\section{FIGURE LEGENDS}

377

378 Figure 1: Diagram of a rower at catch (black) and finish (grey) positions on the stationary (a)

379 and dynamic ergometer (b). It can be observed the greater horizontal displacement of the rower's

380 center of mass on stationary ergometer.

381

382

383 Figure 2: Mean \pm SD of gross (a) and net efficiency (b) for SRE ( $\square$ ) and DRE ( $\mathbf{a}$ ) ergometer at $38460 \%$ and $70 \% \mathrm{P}_{\text {peak. }}$ *: statistical difference between SRE and DRE and between $60 \%$ and $70 \%$ $385 \quad P_{\text {peak }}$ with $\mathrm{p} \leq 0.05$.

386 
Table 1: Effect of exercise Intensity, Ergometer and their interaction during standardized submaximal exercise on SRE and DRE.

\begin{tabular}{|c|c|c|c|c|c|c|c|}
\hline & \multicolumn{2}{|c|}{$60 \%$} & \multicolumn{2}{|c|}{$70 \%$} & \multirow{2}{*}{ Intensity } & \multirow{2}{*}{ Ergometer } & \multirow{2}{*}{ Crossed } \\
\hline & SRE & DRE & SRE & DRE & & & \\
\hline$N$ & 11 & 11 & 11 & 11 & & & \\
\hline \multicolumn{8}{|c|}{ Mechanical, physiological and psychological data } \\
\hline Power (W) & $176.4 \pm 44.8$ & $176.8 \pm 44.5$ & $206.0 \pm 53.2$ & $206.8 \pm 53.8$ & $\mathrm{p}<0.05$ & NS & NS \\
\hline Heart rate (beats/min) & $163 \pm 14$ & $168 \pm 12$ & $171 \pm 14$ & $176 \pm 12$ & $\mathrm{p}<0.05$ & $\mathrm{p}<0.001$ & NS \\
\hline RPE (6-20) & $11 \pm 2$ & $11 \pm 2$ & $13 \pm 2$ & $13 \pm 2$ & $\mathrm{p}<0.05$ & NS & NS \\
\hline$\Delta[\mathrm{La}]\left(\mathrm{mmol} .1^{-1}\right)$ & $0.77 \pm 0.39$ & $0.63 \pm 0.36$ & $1.28 \pm 0.83$ & $1.09 \pm 0.67$ & $\mathrm{p}<0.05$ & $\mathrm{p}<0.05$ & NS \\
\hline $\mathrm{VO}_{2}\left(1 . \mathrm{min}^{-1}\right)$ & $3,35 \pm 0,84$ & $3,51 \pm 0,84$ & $3,65 \pm 0,82$ & $3,87 \pm 0,88$ & $\mathrm{p}<0.05$ & $\mathrm{p}<0.05$ & NS \\
\hline $\mathrm{VCO}_{2}\left(1 . \mathrm{min}^{-1}\right)$ & $2,99 \pm 0,77$ & $3,12 \pm 0,77$ & $3,44 \pm 0,84$ & $3,62 \pm 0,87$ & $\mathrm{p}<0.05$ & $\mathrm{p}<0.05$ & NS \\
\hline Gross efficiency (\%) & $15.4 \pm 0.9$ & $14.7 \pm 0.9$ & $16.2 \pm 1.1$ & $15.4 \pm 1.2$ & $\mathrm{p}<0.05$ & $\mathrm{p}<0.05$ & NS \\
\hline Net efficiency $(\%)$ & $17.2 \pm 1.2$ & $16.4 \pm 1.0$ & $17.9 \pm 1.3$ & $16.9 \pm 1.3$ & $\mathrm{p}<0.05$ & $\mathrm{p}<0.05$ & NS \\
\hline & & & nematic data & & & & \\
\hline Stroke rate $\left(\mathrm{min}^{-1}\right)$ & $18 \pm 1$ & $19 \pm 2$ & $19 \pm 2$ & $20 \pm 1$ & $\mathrm{p}<0.05$ & $\mathrm{p}<0.05$ & NS \\
\hline
\end{tabular}

Georg Thieme Verlag KG. P. O. Box 3011 20, D-70451 Stuttgart, Germany. http://www.thieme.de/fz/sportsmed/index.html 
Manuscript submitted to editorial office

Page 20 of 21

1
2
3
4
5
6
7
7
8
9
10
11
12
13
14
15
16
17
18
19
20
21
22
23
24
25
26
27
28
28
29
30
31
32
33
34
35
36
3
3

Georg Theme Verlag KG. P. O. Box 3011 20, D-70451 Stuttgart, Germany. http://www.thieme.de/fz/sportsmed/index.html 
1

2

3

4

5

6

7

8

9

10

11

12

13

14

15

16

17

18

19

20

21

22

23

24

25

26

27

28

29

30

31

32

33

34

35

36

37

38

39

40

41

42

43

44

45

46

47

48

49

50

51

52

53

54

55

56

57

58

59

60
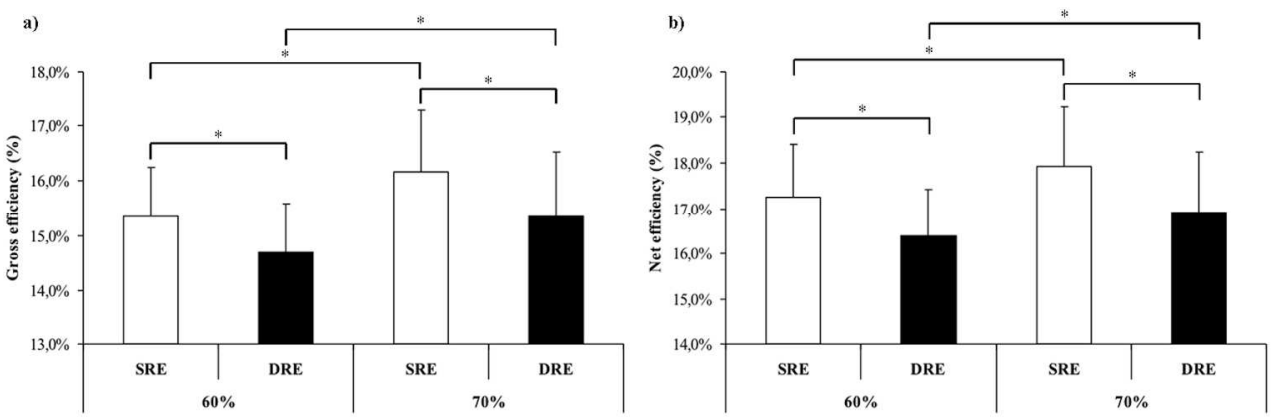

Figure 2

$244 \times 82 \mathrm{~mm}(300 \times 300$ DPI $)$ 